\title{
Characterization of sheep populations of Kenya using microsatellite markers: Implications for conservation and management of indigenous sheep populations
}

\author{
A.W.T. Muigai ${ }^{1 \#}$, A.M. Okeyo ${ }^{2}$, A.K. Kwallah ${ }^{1,3}$, D. Mburu ${ }^{2,4}$ and O. Hanotte ${ }^{2,5}$ \\ ${ }^{1}$ Department of Botany, Jomo Kenyatta University of Agriculture \& Technology, P.O. Box 62000-00200 Nairobi, \\ Kenya \\ ${ }^{2}$ Biotechnology Theme, International Livestock Research Institute, P. O. Box 30709-00100, Nairobi, Kenya \\ ${ }^{3}$ Department of Pathology, IDAC Laboratories, P.O. Box 7133, Al-Kharj 11942, Saudi Arabia \\ ${ }^{4}$ International Centre for Infectious Diseases, P. O. Box 30197, Nairobi, Kenya \\ ${ }^{5}$ School of Biology, University of Nottingham, Nottingham NG7 2RD, UK
}

\begin{abstract}
Indigenous sheep of Kenya are very important to resource-poor farmers and pastoralists. They have over time adapted to the harsh environmental conditions of the arid and semi-arid lands where they are faced with challenges of persistent droughts, diseases, conflicts and poor nutrition, yet show resistance to gastrointestinal nematodes. In recent years, these indigenous sheep populations have been crossbred indiscriminately to exotic breeds particularly the Dorper. A study was undertaken to determine the level of genetic diversity and relatedness between the various sheep populations and breeds of Kenya. This paper reports results on the genetic diversity and admixture observed using microsatellite DNA markers.
\end{abstract}

Keywords: Indigenous Kenyan sheep, microsatellite DNA markers, genetic diversity, admixture

\#Corresponding author. Email: a.muigai@cgiar.org

\section{Introduction}

Indigenous genetic resources of Africa and the world at large are threatened with extinction (FAO, 2000; 2007). In sub-Saharan Africa it has been estimated that $30 \%$ of the indigenous genetic resources are at risk of becoming extinct before they are characterised and documented (Rege et al., 1996). The indigenous sheep of Kenya can be classified as fat-tailed or fat-rumped (Rege et al., 1996). These include the Red Maasai (Figure 1a) and the East African Fat Tailed (Figure 1b). These sheep are faced with many challenges including persistent droughts, diseases, conflicts and poor nutrition (Kosgey et al., 2008). Their ability to walk long distances in search of pasture and adaptability to the harsh environmental conditions (Owen et al., 2005) and together with some unique traits, like resistance to gastrointestinal nematodes (Baker et al., 2002) increases their importance to resource-poor farmers and pastoralists. However, the greatest challenge being faced by these populations is the indiscriminate cross breeding with exotic breeds and especially with the Dorper (Figure 1c) and causing increasing threat to this unique breed, with possibility of extinction. This study was undertaken to characterize the indigenous breeds of Kenya at the molecular level in order to provide information on the risk status of the sheep breeds with the goal of using the information generated for their conservation and rational management.

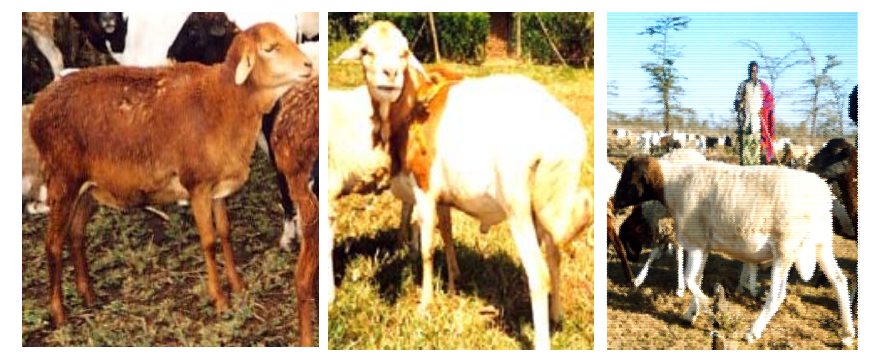

Figure 1 a-c The sheep of Kenya. (a) Red Maasai (b) East African Fat-tailed (c) Exotic Dorper sheep. 


\section{Materials and Methods}

Nine sheep populations were sampled from the West of the Rift Valley (Migori, Homa Bay/Kendu Bay, Transmara and Kakamega) and the East of the Rift Valley (Kajiado, Naivasha/Olmagogo, Laikipia East and Laikipia West) of Kenya (Table 1). DNA was extracted from blood (Sambrook et al., 1989) and amplified using 15 DNA microsatellite markers selected from a joint committee of FAO and International Society for Animal Genetics (ISAG) list of markers (OARFCB20, TGLA53, MCM42, OARVH72, BM8125, ILSTS11, OARJMP29, OARFCB11, ILSTS005, MAF209, SRCRSP5, DYMS1, SRCRSP9, MAF214, OARFCB226). The PCR products were separated using an ABI 3730 DNA analyzer. The data was analysed by GeneMapper ${ }^{\circledR}$ software (version 3.7, Applied Biosystems). The third order least squares method was used for size calling. The genetic diversity for each population was assessed by calculating the mean number of alleles, using the programme, MICROSATELLITE TOOLKIT, (Park, 2001) and the expected heterozygosity and its standard errors using DISPAN (Ota, 1983).

Table 1 Population, type, sampling location, number of individuals, expected heterozygosity $\left(H_{e}\right)$ and mean number of alleles (MNA) per locus of the populations studied

\begin{tabular}{cccccc}
\hline Population & Type & $\begin{array}{c}\text { Sampling } \\
\text { location* }\end{array}$ & Number & MNA & HE \pm s.e. \\
\hline Red Maasai-Mutara & Fat - tailed & East Rift Valley & 48 & 6.16 & $0.70 \pm 0.03$ \\
Red Maasai-Olmagogo & Fat - tailed & East Rift Valley & 47 & 5.88 & $0.66 \pm 0.03$ \\
Kakamega & East African Fat Tailed & West Rift Valley & 30 & 6.65 & $0.70 \pm 0.03$ \\
Migori & East African Fat Tailed & West Rift Valley & 30 & 6.14 & $0.66 \pm 0.03$ \\
Transmara & East African Fat Tailed & West Rift Valley & 40 & 6.40 & $0.70 \pm 0.03$ \\
Dorper Laikipia East & Dorper & East Rift Valley & 30 & 6.37 & $0.71 \pm 0.25$ \\
Dorper Laikipia West & Dorper & East Rift Valley & 30 & 6.59 & $0.71 \pm 0.03$ \\
Homabay & East African Fat Tailed & West Rift Valley & 32 & 5.61 & $0.64 \pm 0.03$ \\
Red Maasai-Kajiado & Red Maasai & East Rift Valley & 47 & 5.69 & $0.68 \pm 0.03$ \\
Mean & & & & 6.16 & $0.68 \pm 0.03$ \\
\hline
\end{tabular}

The genetic relationships between the sheep breeds were calculated using Nei's genetic distances $(D a)$ (Nei et al., 1983) and a neighbour-joining tree was constructed using the DISPAN programme (Ota, 1983). Population admixture analysis using a Bayesian clustering approach was performed using the STRUCTURE programme (Pritchard et al., 2000).

\section{Results and Discussion}

High mean number of alleles and high expected heterozyosities were observed for all populations sampled, giving an indication of high genetic diversities within the populations (Table 1). The phylogenetic analysis showed two main clusters of sheep, the indigenous populations of Kenya and the exotic populations (Figure 1). The Red Maasai populations sampled from Mutara and Olmagogo (Naivasha) clustered together (Figure 1). However, the Red Maasai sampled from Kadjiado clustered together with the two Dorper populations sampled from Laikipia East and West (Figure 1). This result is supported by the population admixture analyses (Figure 2) which show the Kadjiado Red Maasai grouping with the two Dorper populations at $\mathrm{K}=3$. 


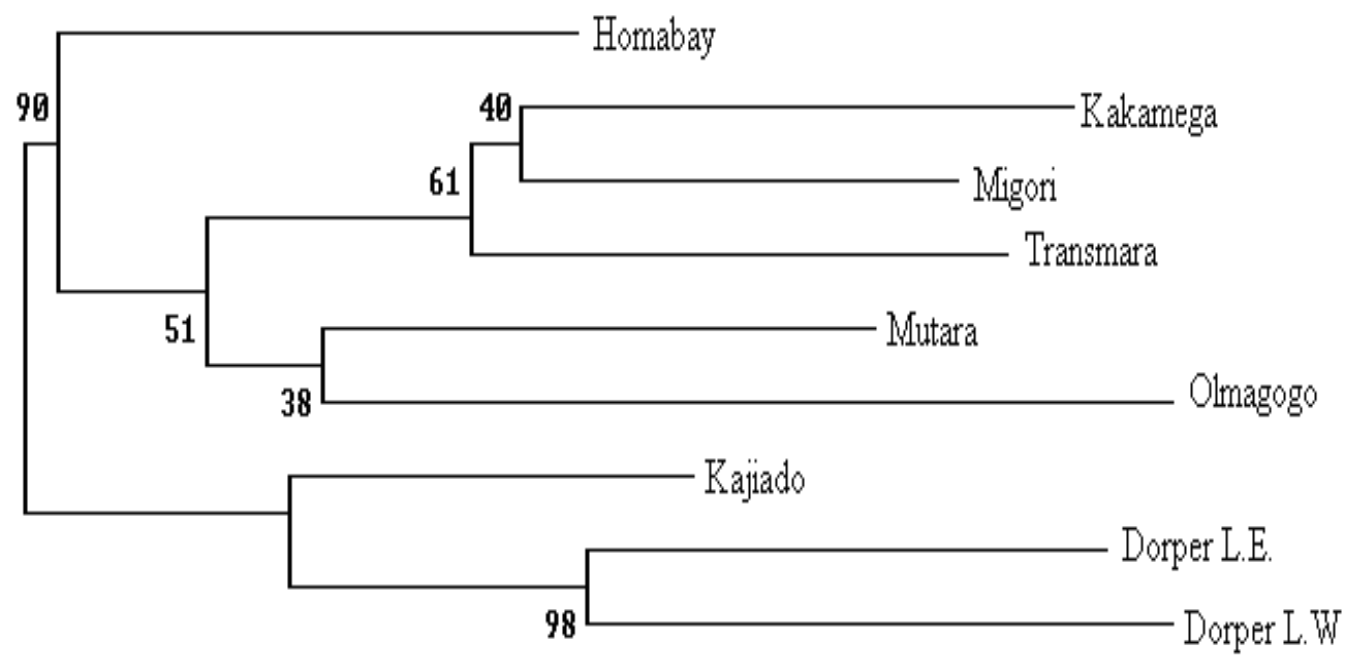

Figure $1 D_{A}$ Phylogenetic tree representing the genetic relationship between the Kenyan Sheep Key: Dorper L.E. = Laikipia East Dorper; Dorper L.W. = Laikipia West Dorper.
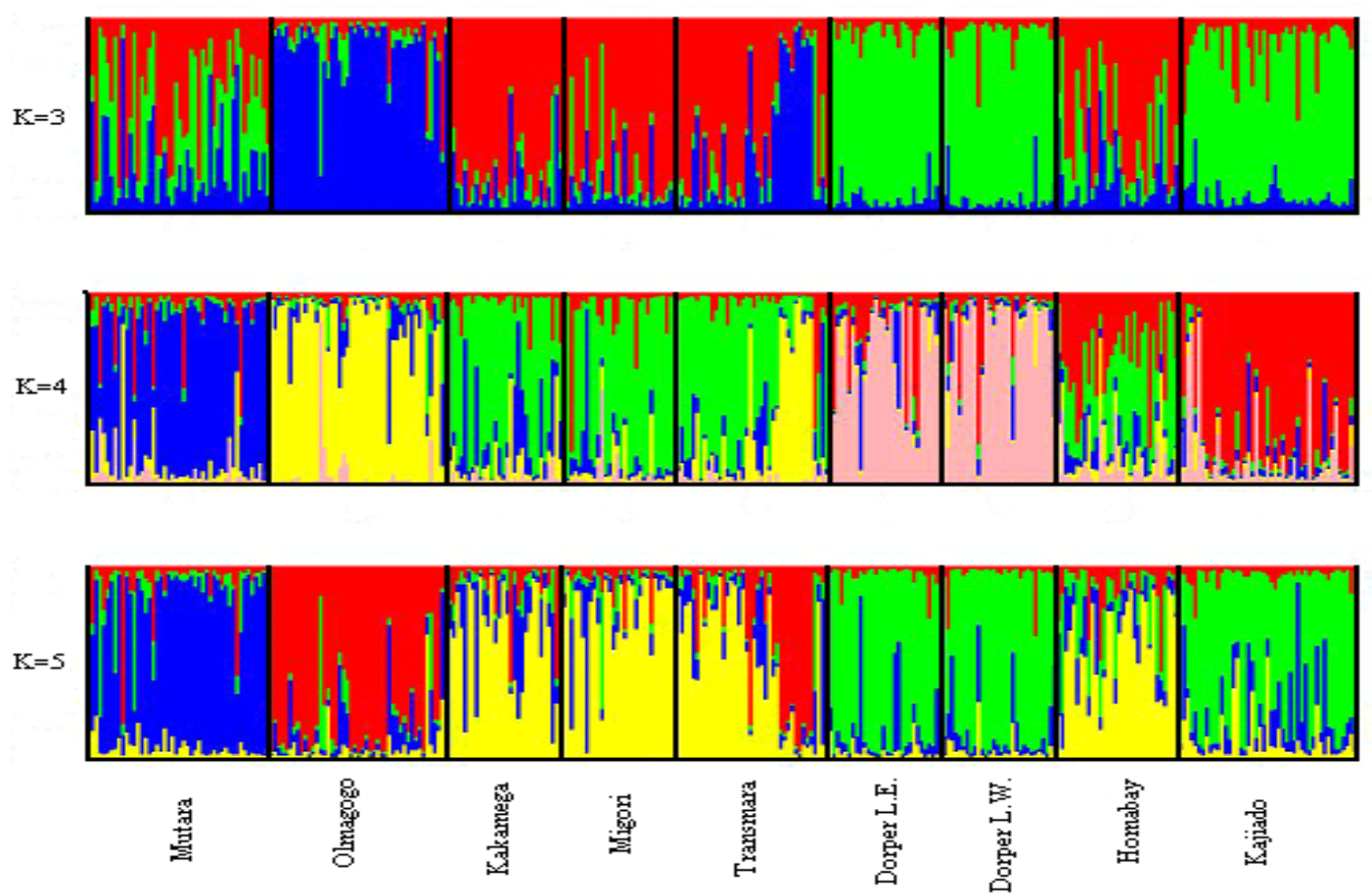

Figure 2 Population admixture analyses using allele frequency data from 15 microsatellite loci typed in 9 sheep populations.

\section{Conclusions}

There is massive introgression of the Dorper genes into the indigenous Red Maasai sheep population, in contrast to the situation 15 years earlier, thus causing genetic dilution and threat of this unique indigenous breed. The results also show that the indigenous population in Homabay and the government managed Red Maasai nucleus flock at Olmagogo show the greatest distinctness - a rare example where concerted efforts by a developing country government has resulted in sustainably conserving and improving an indigenous sheep breed, through an ex-situ live method. 


\section{Acknowledgement}

Financial support for this work was provided by the International Foundation for Science (IFS) and Conservation, Food and Health Foundation.

\section{References}

Baker, R.L., Mugambi, J.M., Audho, J.O., Carles, A.B. \& Thorpe, W., 2002. Comparison of Red Maasai and Dorper sheep for resistance to gastro-intestinal nematode parasites, productivity and efficiency in a humid and semi-arid environment in Kenya. In: Proc. 7th World Congress of Genetics Applied to Livestock Production. Montpellier, France, 19-23 August, 2002. pp. 639-642.

FAO, 2000. "World Watch List for domestic animal diversity," FAO, Rome.

FAO, 2007. Report on the International Technical Conference on Animal Genetic Resources for Food and Agriculture, Interlaken Switzerland, September 2007.

Kosgey, I.S., Rowlands, G.J., Van Arendonk, J.A.M. \& Baker, R.L., 2008. Small ruminant production in small holder and pastoral/extensive farming systems in Kenya. Small Rumin. Res. 77, 11-24.

Nei, M., Tajima, F. \& Tateno, Y., 1983. Accuracy of estimated phylogenetic trees from molecular data. II. Gene frequency data. J. Mol. Evol. 19, 153-170.

Ota, T., 1993. Dispan: Genetic Distance and Phylogenetic Analysis. Pennsylvania, Pennsylvania State University.

Owen, E., Kitalyi, A., Jayasuriya, N. \& Smith, T. 2005. Livestock and wealth creation. Improving the husbandry of animals kept by resource-poor people in developing countries Nottingham University Press, UK.

Park, S.D.E., 2001. Trypanotolerance in West African cattle and the population genetic effects of selection. $\mathrm{PhD}$ thesis, University of Dublin, Ireland.

Pritchard, J.K., Stephens, M. \& Donnelly, P., 2000. Inference of population structure using multilocus genotype data. Genetics 155, 945-959.

Rege, J.E.O., Yapi-Gnaore, C.V. \& Tawah, C.L., 1996. The indigenous domestic ruminant genetic resources of Africa. In: 2nd All Africa Conference on Animal Agriculture, 1-4 April 1996, Pretoria, South Africa.

Sambrook, J., Fritsch, E.F. \& Maniatis, T., 1989. Molecular Cloning: a Laboratory Manual. $2^{\text {nd }}$ edition. Cold Spring Harbour Laboratory Press, New York. 